\title{
EVALUATION OF AERIAL BIOMASS YIELD AND ESSENTIAL OIL CONTENT OF SEVEN SPECIES OF TANACETUM
}

\author{
Mohammad Ali ALIZADEH*, Ali Ashraf JAFARI, Sayed Esmaiel SAYEDIAN \\ Gene Bank Natural Resources, Research Institute of Forests and Rangelands, \\ Agricultural Research Education and extension Organization (AREEO), Tehran, Iran \\ Received: November 2016; Accepted: May 2017
}

\begin{abstract}
To evaluate the seven species of Tanacetum genus - Tanacetum balsamita, T. parthenium, T. pinnatum, T. polycephalum, T. tabrisianum, T. uniflorum, and T. vulgare - an experiment was conducted in Karaj Iran. Data were recorded for plant canopy cover, plant height, flower number per plant, aerial biomass yield, time required for flowering, growing degree days to flowering (GDD), essential oil percentage and yield. Results showed that $T$. parthenium had higher mean values for plant canopy cover, plant height and flower number per plant whereas the species of T. parthenium, T. balsamita and T. vulgare had higher aerial biomass yield in comparison to the other species. The $T$. balsamita coupled with aerial biomass yield had the highest essential oil concentration. The T. tabrisianum and $T$. uniflorum were earliest ripening species due to lowest GDD. Essential oil yield was positively and significantly correlated with the traits that are components of aerial mass, indicating that selection for breeding new cultivars should focus on increased aerial biomass yield, late flowering and high flower number.
\end{abstract}

Key words: Tanacetum spp., aerial biomass yield, essential oil concentration

\section{INTRODUCTION}

Tanacetum genus (family Asteraceae, tribe Anthemideae) contains perennial and herbaceous plants (Mozafarian 1996). To this genus belong 160 species that are scattered in Europe, Asia, North Africa, and South America (Oberprieler et al. 2007). The origin of Tanacetum genus is southwest of Asia and Caucasus (Heywood \& Humphries 1977). The species of Tanacetum are valuable medicinal plants. The flora of Iran has 26 species of Tanacetum, of which 12 are endemic (Mozafarian 1996, 2005). Some members of the Tanacetum genus have been traditionally used in balsams, cosmetics, dyes, insecticides, medicines; they have also been found to act as preservatives in herbal remedies (Grieve 1984). They are used as anthelmintic for migraine, neuralgia, rheumatism and loss of appetite (Blumenthal 1998). According to the recent studies, the oils and extracts of members of the Tanacetum genus exhibit anti-inflammatory (Brown et al. 1997), antibacterial, antifungal (Hethelyi et al. 1991) and insecticidal effects (Hough-Golstein \& Hahn 1992). The terpenes of essential oils are thought to be associated with the biological activity of Tanacetum. Long et al. (2003) reported on medicinal values of sesquiterpenes, lactones, parthenolides and flavonoids of $T$. parthenium. All evaluated species are perennial or biennial.

Tanacetum balsamita grows to 35 to $80 \mathrm{~cm}$ high and is slightly pubescent. Inflorescence diadem is thin and relatively dense. The time of flowering and fruiting is mid-spring to early summer. This species grows in Iranian Turanian and Caspian region and is distributed in northwestern Iran, Europe, Turkey and central Asia (Mozafarian 2008).It has been used for more than several centuries for flavor, carminative and cardiotonic in traditional and folk medicine. Tanacetum parthenium stem grows to 30 to $80 \mathrm{~cm}$, leaves, leaf pieces and racks are soft green. All plant parts emit strong and bitter smell. Tanacetum parthenium is a medicinal herb, rich in 
sesquiterpenes and lactones (Majdi et al. 2013). The species originates from Asia and the Balkans and it scattered in a large area of Europe and Asia (Blumenthal 1998).

Tanacetum pinnatum is a woody species full branches with erect stem 20 to $65 \mathrm{~cm}$, grooved, hairless, with yellowing flower receptacle with a thin tube and often protruded stigma. The achenes are long $(3 \mathrm{~mm})$. The time of flowering and fruiting is early and late summer. This species is scattered in Iranian Turanian region and is distributed in northwestern, western and central Iran (Mozafarian 2008).

Tanacetum polycephalum is perennial or biennial species with multiple fertile and sterile stems, covered with short hairs, gray felt, 20 to $40 \mathrm{~cm}$ height. The time of flowering and fruiting is summer. This species belongs to the Iranian Turanian and Caspian region. It is distributed in northwestern Iran, Turkey, Caucasus and in north of Iraq. The achenes are cylindrical, 2 to $2.5 \mathrm{~mm}$ height.

Tanacetum tabrisianum is known as tabrisianum aster. The plant is 10 to $30 \mathrm{~cm}$ height; its leaves are green to yellowish with surface covered by green to yellowish pubes. The petioles are long and the calyx is tubular with length of 2 to $3.2 \mathrm{~mm}$. The length of achenes is 2.8 to $3.6 \mathrm{~mm}$. The time of flowering and fruiting is early summer. This species is distributed in the Iranian Turanian region and in the western and central Iran (Mozafarian 2008), Turkey and Caucasus.

Tanacetum uniflorum has woody full branches stems of 30 to $55 \mathrm{~cm}$ height. The flowers are yellow with convex receptacle 7 to 10 tubular flowers. The fruit is brown achenes and yellow straw. The time of flowering and fruiting is late spring and summer. This species grows in the Iranian Turanian region and is distributed in the northwestern Iran, Turkey and Caucasus (Mozafarian 2008).

Tanacetum vulgare (syn. Chrysanthemum vulgare (L.) Bernh.] (Common tansy) has erect stems that can reach $2 \mathrm{~m}$ in height. It is an aromatic plant that stores monoterpenoids predominantly in its leaves (Kleine \& Müller 2013). Coarse stems generally branch only at the top and are somewhat woody at the base. Stems may grow singly or in clusters and they are lined with alternative leaves. As a plant containing many useful substances with folk and medical applications, it is harvested from the natural habitats, which can cause deterioration of genetic resources of plant and, this result would be imposing of irreversible destructive effects on the ecological balance of flora and ecosystems (Hassanpour Moghdam et al. 2008).

The aim of this study was to evaluate the seven species of Tanacetum for their morphological and phenological characteristics and essential oil production, and finally to determine the superior species with high aerial biomass and essential oil yield.

\section{MATERIALS AND METHODS}

Seeds of the 7 species as: Tanacetum balsamita, T. parthenium, T. pinnatum, T. polycephalum, T. tabrisianum, T. uniflorum and T. vulgare, were provided from the Natural Resource Gene Bank of Research Institute of Forest and Rangelands, Tehran, Iran. For each species, 90 seeds were sown in Jiffy pots in glasshouse in Feb 2012. Then, the seedlings were transplanted in the field conditions in Alborz research station in Karaj, Iran in March 2013. The experiment was established in a randomized complete block design (RCBD) with three replications. Each unit of experiment consisted of six rows, $50 \mathrm{~cm}$ apart from each other, with the distance of plants in rows as $40 \mathrm{~cm}$ (30 plants in each experimental unit).

Data were collected in the next year of planting. In each plot, 10 plants in the middle of plots were selected for the measurement of yield and morphological traits and averaged as mean of each plot. The following traits were analyzed: plant canopy cover area $\left(\mathrm{cm}^{2}\right)$, plant height $(\mathrm{cm})$, flower number per plant, time required for flowering (days), aerial biomass yield $\left(\mathrm{kg} \cdot \mathrm{ha}^{-1}\right)$, growing degree days to flowering (GDD), essential oil concentration and essential oil yield $\left(\mathrm{kg} \cdot \mathrm{ha}^{-1}\right)$. The canopy cover area was estimated using the means of width and length diameters of the plant canopy. Time required for flowering was recorded as the number of days from date 21 March (the starting point of growing - the first day of Iranian New Year in spring season) till the emergence of the first flower on plant. The aerial plant parts were harvested in full flowering stage, 
weighed, air dried in room temperature for one week and weighed again to obtain as aerial biomass yield. GDD for flowering stage was calculated as follows:

$$
\mathrm{GDD}=\frac{\mathrm{T}_{\min }+\mathrm{T}_{\max }}{2}-\mathrm{T}_{b}
$$

where:

GDD = growing degree days

$\mathrm{T}_{\max }=$ maximum daily temperature (mean for days from March 21 till full bloom)

$\mathrm{T}_{\min }=$ minimum daily temperature (as above)

$\mathrm{T}_{\mathrm{b}}=$ the base temperature [physiological zero for germination, for those species as $\left(6^{\circ} \mathrm{C}\right)$, (Alizadeh \& Jafari 2016). The maximum and minimum daily temperatures were provided from Karaj, Iran Metrological Station (IRIMO 2011).

The essential oil was extracted using the hydro distillation method with a Clevenger type apparatus. Each sample containing 10 plants per plots were harvested at full flowering stage and dried and ground. The materials of every species ( $80 \mathrm{~g}$ in three replications) were placed in a 3 liter round-bottomed flask containing 1.5 L of water and refluxed for $3 \mathrm{~h}$. After completion, the oil volume (mL) was recorded according to the Hungarian plant pharmocopy letter (Anonymous 1984) as follow:

$$
\text { Essential oil content } \%=\frac{\text { Essential oil weight } g}{\text { Aerial biomassyieldg }} \times 100
$$

Essential oil yield was calculated by essential oil\% $\times$ aerial biomass yield $\left(\mathrm{kg} \cdot \mathrm{ha}^{-1}\right)$.
The collected data were subjected to the analysis of variance and mean comparisons were made using the Tukey method. Phenotypic correlations among characteristics were estimated for all pairwise combinations. All the variables averaged over plots were used in principal component and cluster analysis. Principal component analysis is often used prior to cluster analysis to determine the relative importance of variables classification (Jackson 1991). The variables were standardized for cluster analysis (Ward 1963). The Minitab 16 (2012) was used for multivariate analysis.

\section{RESULTS AND DISCUSSION}

\section{Analysis of variance and means comparisons}

The results of analysis of variance (ANOVA) showed significant variation for all the measured traits $(\mathrm{p}<0.01)$ (Table 1$)$. The means comparison of all the species for canopy cover, plant height, flower number, aerial biomass yield, time required for flowering, GDD, essential oil percentage and essential oil yield are presented in Table 2 . The highest number of days to flower and highest value of GDD (115 days and $1284{ }^{\circ} \mathrm{C}$ respectively) were obtained for T. balsamita.. T. parthenium and T. vulgare were classified in the same group of significance. The lowest values of these two traits was found for $T$. uniflorum (70 days and $491{ }^{\circ} \mathrm{C}$ respectively). In the same group of significance were classified $T$. polycephalum and T. tabrisianum (Table 2).

Table 1. Analysis of variance in seven species of Tanacetum: T. balsamita, T. parthenium, T. pinnatum, T. polycephalum, T. tabrisianum, T. uniflorum, and T. vulgare

\begin{tabular}{lccccccccc}
\hline Source & DF & $\begin{array}{c}\text { Time to } \\
\text { flowering } \\
\text { (day) }\end{array}$ & $\begin{array}{c}\text { growing de- } \\
\text { gree days }\end{array}$ & $\begin{array}{c}\text { plant } \\
\text { height } \\
(\mathrm{cm})\end{array}$ & $\begin{array}{c}\text { canopy } \\
\text { cover } \\
\left(\mathrm{cm}^{2}\right)\end{array}$ & $\begin{array}{c}\text { flower } \\
\text { number per } \\
\text { plant }\end{array}$ & $\begin{array}{c}\text { aerial bio- } \\
\text { mass yield } \\
\left(\mathrm{kg} \cdot \mathrm{ha}^{-1}\right)\end{array}$ & $\begin{array}{c}\text { essential } \\
\text { oil \% }\end{array}$ & $\begin{array}{c}\text { essential oil } \\
\text { yield } \\
\left(\mathrm{kg} \cdot \mathrm{ha}^{-1}\right)\end{array}$ \\
\hline Rep & 2 & 138.2 & 10176 & $253.5^{*}$ & $582.72^{* *}$ & 4914.5 & 622.2 & 0.008 & 0.125 \\
Species & 6 & $5316^{* *}$ & $1569982^{* *}$ & $8474.2^{* *}$ & $2124083^{* *}$ & $356490 * *$ & $310346^{* *}$ & $0.395^{* *}$ & $226.6 * *$ \\
Error & 169 & 96 & 8756 & 113.6 & 1845.91 & 3963 & 7295.84 & 0.035 & 7.30 \\
\hline $\begin{array}{l}\text { Coefficient of } \\
\text { variation \% }\end{array}$ & 0.14 & 0.14 & 17.17 & 35.61 & 49.37 & 9.47 & 12.71 & 21.69 \\
\hline
\end{tabular}

*significant at the 0.05 probability level, ** significant at the 0.01 probability level. 
Table 2. Morphological and phenological traits in seven species of Tanacetum

\begin{tabular}{lcccccccc}
\hline $\begin{array}{c}\text { Name of } \\
\text { species }\end{array}$ & $\begin{array}{c}\text { Time to } \\
\text { flowering } \\
\text { (day) }\end{array}$ & $\begin{array}{c}\text { Growing } \\
\text { degree } \\
\text { days }\end{array}$ & $\begin{array}{c}\text { Plant } \\
\text { height } \\
(\mathrm{cm})\end{array}$ & $\begin{array}{c}\text { Canopy } \\
\text { cover } \\
\left(\mathrm{cm}^{2}\right)\end{array}$ & $\begin{array}{c}\text { Flower } \\
\text { number } \\
\text { per/plant }\end{array}$ & $\begin{array}{c}\text { Aerial } \\
\text { biomass } \\
\text { yield } \\
\left(\mathrm{kg}^{2} \cdot \mathrm{ha}^{-1}\right)\end{array}$ & $\begin{array}{c}\text { Essential } \\
\text { oil \% }\end{array}$ & $\begin{array}{c}\text { Essential } \\
\text { oil yield } \\
\left(\mathrm{kg} \cdot \mathrm{ha}^{-1}\right)\end{array}$ \\
\hline T. balsamita & $115 \mathrm{a}$ & $1285 \mathrm{a}$ & $58 \mathrm{ab}$ & $993 \mathrm{~b}$ & $109 \mathrm{~b}$ & $3174 \mathrm{a}$ & $0.59 \mathrm{a}$ & $18 \mathrm{a}$ \\
T. parthenium & $102 \mathrm{a}$ & $1028 \mathrm{a}$ & $61 \mathrm{a}$ & $1788 \mathrm{a}$ & $243 \mathrm{a}$ & $2570 \mathrm{a}$ & $0.22 \mathrm{c}$ & $5 \mathrm{~b}$ \\
T. pinnatum & $87 \mathrm{~b}$ & $765 \mathrm{~b}$ & $17 \mathrm{~d}$ & $94 \mathrm{c}$ & $6 \mathrm{c}$ & $166 \mathrm{~b}$ & $0.34 \mathrm{~b}$ & $0.6 \mathrm{~d}$ \\
T. polycephalum & $75 \mathrm{bc}$ & $574 \mathrm{bc}$ & $29 \mathrm{~cd}$ & $498 \mathrm{bc}$ & $10 \mathrm{c}$ & $586 \mathrm{~b}$ & $0.45 \mathrm{ab}$ & $3 \mathrm{c}$ \\
T. tabrisianum & $74 \mathrm{bc}$ & $545 \mathrm{bc}$ & $18 \mathrm{~d}$ & $140 \mathrm{c}$ & $7 \mathrm{c}$ & $140 \mathrm{c}$ & $0.31 \mathrm{~b}$ & $0.5 \mathrm{~d}$ \\
T. uniflorum & $70 \mathrm{bc}$ & $491 \mathrm{c}$ & $36 \mathrm{~b}-$ & $298 \mathrm{bc}$ & $14 \mathrm{c}$ & $326 \mathrm{~b}$ & $0.15 \mathrm{~d}$ & $0.4 \mathrm{~d}$ \\
T. vulgare & $110 \mathrm{a}$ & $1184 \mathrm{a}$ & $64 \mathrm{a}$ & $891 \mathrm{bc}$ & $31 \mathrm{bc}$ & $2690 \mathrm{a}$ & $0.12 \mathrm{~d}$ & $3 \mathrm{bc}$ \\
\hline
\end{tabular}

The means in columns indicated by the same letter do not differ significantly based on DMRT at $\mathrm{p}=0.05$.

Table 3. Phenotypic correlation coefficients between essential oil yield and morphological traits in seven species of Tanacetum

\begin{tabular}{|c|c|c|c|c|c|c|c|}
\hline Traits name & $\begin{array}{l}\text { Time to } \\
\text { flowering } \\
\text { (day) }\end{array}$ & $\begin{array}{c}\text { Growing } \\
\text { degree } \\
\text { days }\end{array}$ & $\begin{array}{l}\text { Plant } \\
\text { height } \\
(\mathrm{cm})\end{array}$ & $\begin{array}{c}\text { Canopy } \\
\text { cover } \\
\left(\mathrm{cm}^{2}\right)\end{array}$ & $\begin{array}{l}\text { Flower } \\
\text { number } \\
\text { per plant }\end{array}$ & $\begin{array}{c}\text { Aerial } \\
\text { biomass yield } \\
\left(\mathrm{kg} \cdot \mathrm{ha}^{-1}\right)\end{array}$ & $\begin{array}{c}\text { Essential } \\
\text { Oil }(\%)\end{array}$ \\
\hline Growing degree days & $0.99 * *$ & & & & & & \\
\hline Plant height & $0.82 * *$ & $0.83 * *$ & & & & & \\
\hline Canopy cover & $0.69 * *$ & $0.68 * *$ & $0.85 * *$ & & & & \\
\hline Number of flower & $0.56^{*}$ & $0.55^{*}$ & $0.66^{* *}$ & $0.93 * *$ & & & \\
\hline Aerial biomass yield & $0.94 * *$ & $0.94 * *$ & $0.94 * *$ & $0.83 * *$ & $0.67 * *$ & & \\
\hline Essential oil \% & 0.17 & 0.18 & -0.15 & -0.06 & 0.02 & 0.12 & \\
\hline Essential oil yield & $0.73 * *$ & $0.74 * *$ & $0.58 *$ & $0.50 *$ & $0.47 *$ & $0.76 * *$ & $0.67 * *$ \\
\hline
\end{tabular}

*significant at the 0.05 probability level, $* *$ significant at the 0.01 probability level

The highest value of canopy cover $\left(1788 \mathrm{~cm}^{2}\right)$ and number of flowers but also long time to flowering and GDD value was related to T. parthenium compared with other species. The plant height of $T$. parthenium, T. vulgare and T. balsamita $(61,64$ and $58 \mathrm{~cm}$ ) were the highest in comparison with the other species. Two species of T. tabrisianum and T. pinnatum had the lowest plant height (18 and $17 \mathrm{~cm})$ and canopy cover as well as flower number (6 and 7) per plant. The aerial biomass yield of T. balsamita, T. parthenium and T. vulgare with average values of 3174,2570 and $2690 \mathrm{~kg} \cdot \mathrm{ha}^{-1}$, respectively, were higher than other species and $T$. $t a$ brisianum and T. uniflorum had the lowest values (140 kg $\cdot \mathrm{ha}^{-1}$ and 166) (Table 2). The essential oil concentration and essential oil yield was highest for T. balsamita $\left(0.59 \%, 18 \mathrm{~kg} \cdot \mathrm{ha}^{-1}\right)$ (Table 2). T. polycephalum was also rich in essential oils $(0.45 \%)$ but due to low aerial biomass, oil yield was only $3 \mathrm{~kg} \mathrm{~h}^{-1}$. The variation for morphological traits between the species is a normal phenomenon, although it is not always correlated with oil yield (Alizadeh et al. 2015a).

\section{Correlation between traits}

The time required for flowering and GDD had the same trend in relationships with other traits. GDD was positively correlated with other traits except essential oil \% (p=0.01) (Table 3). Similarly, aerial biomass yield was positively correlated with other traits except essential oil \% ( $\mathrm{p}=0.01)$. The relationships between plant height, canopy cover and flower number were positive with other traits except essential oil \%. Adeli et al. (2013) and Alizadeh et al. (2015b) found high positive correlation between flower number with plant height and canopy cover. Essential oil yield had positive and significant correlations with all the traits. There was strong correlation between essential oil yield and essential oil \%. This result was in agreement with the results of Soluki et al. (2008) and Pirkhezri et al. (2010) in Matricaria chamomilla and Hamisy et al. 
(2012), in Tanacetum parthenium also found positive correlation between essential oil \%, flower number and aerial biomass yield.

\section{Classification of species}

The results of PCA analysis showed that the first two components accounted for 73 and 17 of the total variation. Canopy cover, plant height, flower number, aerial biomass yield, time required for flowering and GDD in the PCA1, and essential oil percentage and essential oil yield in the PCA2 were identified as the important traits for classification(Table 4). Using the Ward cluster method, the seven species were grouped into two clusters (Fig. 1). With T. balsamita, T. parthenium and T. vulgare in the cluster 1 and the species of $T$. pinnatum, $T$. polycephalum, $T$. tabrisianum and T. uniflorum in the cluster 2 (Figs 1).

The species in the cluster 1 considered as late maturity because it needed more time for flowering and higher GDD and had the highest aerial biomass yield. The species in Cluster 2 had lower values for all of traits except the essential oil \%. The mean percentage of essential oil was similar in both clusters with average values of $0.31 \%$ (Table 5).

Fig. 2 shows how the accessions are classified into two clusters according to the first two principal components. By the scatter of seven species eigenvectors, the first component separated clusters 1 and 2 with trend of low to high yield and other morphological traits. The second component well separated species in clusters based on their essential oil \% and essential oil yield. In cluster 1, the species of $T$. balsamita, $T$. parthenium and $T$. vulgare that had higher essential oil yield separated from cluster 2 (T. pinnatum, T. polycephalum, T. tabrisianum and T. uniflorum) with lower values of essential oil yield (Fig. 2). This result indicated that the distribution of species based on the first two component scores are in agreement with cluster analysis.

With a similar method, Alizadeh and Jafari (2016) used cluster analysis for the grouping of accession of Anthemis triumfettii, A. tinctoria, A. haussknechtii and A. pseudocotula. According of their result, the cluster analysis well separated the accession based on aerial biomass yield, morphological traits and GDD. In some items, the accessions within each cluster were coordinated with their geographical provenance.

By a study of multivariate statistical analysis of 58 morphological characters using Ward cluster and principal component analyses, Kazemi et al. (2014) found that Tanacetum aureum, T. oligocephalum and T. heimerlii well differentiated as separate species.

Table 4. Matrix of coefficients eigenvectors and variance proportion from the first two principal component axes in seven species of Tanacetum: T. balsamita, T. parthenium, T. pinnatum, T. polycephalum, T. tabrisianum, T. uniflorum, and T. vulgare

\begin{tabular}{lcc}
\hline \multicolumn{1}{c}{ Variable } & PC1 & PC2 \\
\hline Time required for flowering (day) & $\mathbf{0 . 3 7}$ & -0.07 \\
Growing degree days & $\mathbf{0 . 3 7}$ & -0.08 \\
Plant height & $\mathbf{0 . 3 6}$ & 0.24 \\
Canopy cover & $\mathbf{0 . 3 4}$ & 0.27 \\
Number of flower & $\mathbf{0 . 3 0}$ & 0.21 \\
Aerial biomass yield & $\mathbf{0 . 3 9}$ & 0.01 \\
Essential oil \% & 0.07 & $\mathbf{- 0 . 7 7}$ \\
Essential oil yield & 0.31 & $\mathbf{- 0 . 4 7}$ \\
\hline Eigen value & 6.53 & 1.49 \\
Proportion & 0.73 & 0.17 \\
Cumulative & 0.73 & 0.89 \\
\hline
\end{tabular}

* The bold and underline coefficients have significant correlation with the relevant axes. 




Fig. 1. Dendrogram with Ward Linkage and Euclidean Distance

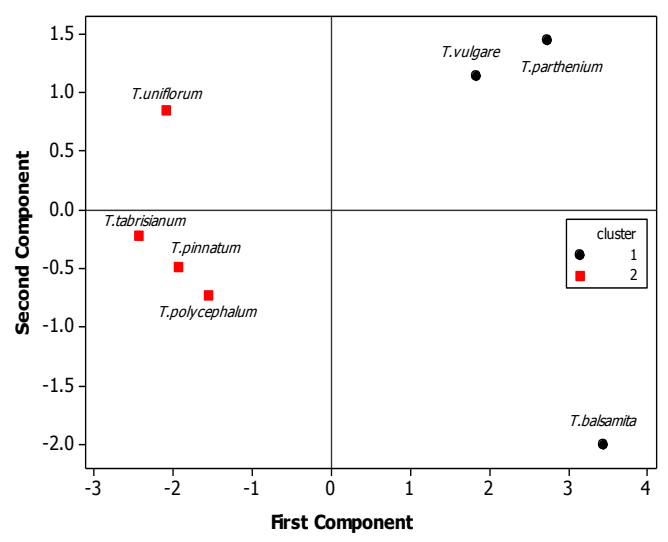

Fig. 2. Scatter plot of seven species and two clusters for the first two principal components

Table 5. Comparisons between means of two clusters for the traits used in classification of Tanaceum

\begin{tabular}{ccccccccc}
\hline $\begin{array}{c}\text { Cluster } \\
\text { No. }\end{array}$ & $\begin{array}{c}\text { Time for } \\
\text { flowering } \\
\text { (day) }\end{array}$ & $\begin{array}{c}\text { Growing } \\
\text { degree } \\
\text { days }\end{array}$ & $\begin{array}{c}\text { Plant } \\
\text { height } \\
(\mathrm{cm})\end{array}$ & $\begin{array}{c}\text { Canopy } \\
\text { cover } \\
\left(\mathrm{cm}^{2}\right)\end{array}$ & $\begin{array}{c}\text { Flower } \\
\text { number } \\
\text { per/plant }\end{array}$ & $\begin{array}{c}\text { Aerial bio- } \\
\text { mass yield } \\
\left(\mathrm{kg} \cdot \mathrm{ha}^{-1}\right)\end{array}$ & $\begin{array}{c}\text { Essential } \\
\text { oil }(\%)\end{array}$ & $\begin{array}{c}\text { Essential } \\
\text { oil yield } \\
\left(\mathrm{kg} \cdot \mathrm{ha}^{-1}\right)\end{array}$ \\
\hline Cluster 1 & 109 & 1166 & 61 & 1224 & 128 & 2811 & 0.31 & 9 \\
Cluster 2 & 76 & 594 & 25 & 258 & 9 & 304 & 0.31 & 1 \\
\hline
\end{tabular}

Cluster $1=T$. balsamita, $T$. parthenium and $T$. vulgare

Cluster $2=T$. pinnatum, $T$. polycephalum, T. tabrisianum and T. uniflorum

\section{CONCLUSION}

It was concluded that the species of $T$. balsamita was superior over other six species because of high aerial biomass yield and essential oil yield. The two species T. tabrisianum and T. uniflorum were considered as the earliest species because of the lowest value of GDD and time required for flowering. The three species of T. balsamita, T. parthenium and $T$. vulgare were considered as late species because of their high value of GDD and time required for flowering.

T. balsamita can be introduced as a superior medicinal plant species for cultivation. There was strong correlation between essential oil yield and essential oil \%. Similarly, essential oil yield had positive and significant correlations with all the traits. Analysis of correlation indicates that the selection for breeding purposes of Tanacetum, should be focused on high aerial biomass yield and essential oil $\%$, which will be correlated with late flowering, plant height and high flower number.

\section{Acknowledgments}

We thank the director and researcher deputy of Research Institute of Forest and Rangeland in Iran for their financial support for this research study and my colleagues in Natural Resource Gene Bank Department.

\section{REFERENCES}

Adeli N., Alizadeh M.A., Jafari A.A. 2013. Evaluation of essential oil yield, morphological and phenological traits in some populations of two Chamomile species (Matricaria recutita and M. aurea). Journal of Medicinal Plants and By-products 2(2): 153-158.

Alizadeh M.A., Jafari A.A. 2016. Variation and relationships of morphological traits, shoot yields and essential oil contents of four Anthemis species. Folia Horticulturae 28(2): 165-172. DOI: 10.1515/fhort2016-0019.

Alizadeh M.A., Khamoshi H., Jafari A.A., Daneshian J. 2015a. Evaluation of some morphological traits, reproductive and therapeutic essential oils of three species of chamomile Anthemis pseudocotula, tinctoria and A. tiumfettii in two sowing date. Iranian 
Journal of Medicinal and Aromatic Plants 30(6): 954-964. [in Persian with English abstract]

Alizadeh M.A., Adeli N., Jafari A.A. 2015b. Variation and relationships of shoot yield, morphological and phenological traits in chamomile populations ( $\mathrm{An}$ themis triumfettii). Journal of Medicinal Plants and By-products 4(1): 111-119.

Anonymous 1984. Hungarian pharmacopoeia, VII Kiadas, I. Kotet, Medicine Publication.

Blumenthal M. 1998. The Complete German Commission E Monographs: Therapeutic Guide to Herbal Medicines. Tansy Flower and Herb. Unapproved Herbs. The American Botanical Council/Integrative Medicine Communications, pp. 379-380.

Brown A.M.G., Edwards C.M., Davey M.R., Power J.B., Lowe K.C. 1997. Effects of extracts of Tanacetum species on human polymarphonuclear leucocyte activity in vitro. Phytotherapy Research 11: 479-484. DOI: 10.1002/(sici)1099-1573(199711)11:7<479::aidptr129>3.3.co;2-n.

Grieve M., Leyel C.F. (ed.) 1984. A modern herbal. Penguin Books Ltd., Middlesex, UK, pp. 789-790.

Hamisi M., Sefidkon F., Nasri M., Lebaschi M.H. 2012. Effects of different amounts of nitrogen, phosphor and bovine fertilizers on essential oil content and composition of Tanacetum parthenium. Iranian Journal of Medicinal and Aromatic Plants 28(3): 399-410. [In Persian with English abstract]

Hassanpouraghdam M.B., Tabatabaie S.J., Nazemiyeh H., Vojodi L., Aazami M.A., Shoja A.M. 2008. Chrysanthemum balsamita (L.) Baill.: a forgotten medicinal plant. Facta Universitatis, Medicine and Biology 15(3): 119-124.

Héthelyi É., Tétényi P., Dános B., Koczka I. 1991. Phytochemical and antimicrobial studies on the essential oils of the Tanacetum vulgare clones by Gas chromatography/Mass spectroscopy. Herba Hungarica 30: 82-90.

Heywood V.H., Humphries C.J. 1977. Anthemideae systematic review. In: Heywood V.H., Harborne J.B., Turner B.L. (Eds.), The biology and chemistry of the Compositae, vol. II. Academic Press, UK, pp. 851-897.

Hough-Goldstein J., Hahn S.P. 1992. Antifeedant and oviposition deterrent activity of an aqueous extract of Tanacetum vulgare L. on two cabbage pests. Environmental Entomology 21: 837-844. DOI: 10.1093/ee/21.4.837.
IRIMO 2011. Meteorological Station of Agricultural College, University of Tehran, Iran. Islamic Republic of Iran Meteorological Organization. Karaj, Iran. http://www.irimo.ir/eng/index.php

Jackson J.E. 1991. A User's Guide to Principal Components. Wiley, New York. DOI: 10.1002/0471725331.

Kazemi M., Sonboli A., ZareMaivan H., Kazempour Osaloo S. 2014. A taxonomic reassessment of the Tanacetum aureum (Asteraceae, Anthemideae) species group: insights from morphological and molecular data. Turkish Journal of Botany 38: 1259-1273. DOI: 10.3906/bot-1404-78.

Kleine S., Müller C. 2013. Differences in shoot and root terpenoid profiles and plant responses to fertilisation in Tanacetum vulgare. Phytochemistry 96: 123-131. DOI: 10.1016/j.phytochem.2013.09.018.

Long C., Sauleau P., David B., Lavaud C., Cassabois V., Ausseil F., Massiot G. 2003. Bioactive flavonoids of Tanacetum parthenium revisited. Phytochemistry 64: 567-569. DOI: 10.1016/S0031-9422(03)00208-5.

Majdi M., Charnikhova T., Bouwmeester H. 2013. Genetical, developmental and spatial factors influencing parthenolide and its precursor costunolide in feverfew (Tanacetum parthenium L. Schulz Bip.). Industrial Crops and Products 47: 270-276. DOI: 10.1016/j.indcrop.2013.03.021.

Mozaffarian V. 1996. A dictionary of Iranian plant names. Farhang Moaser Publishers, Tehran, Iran.

Mozaffarian V. 2005. Notes on the tribe Anthemideae (Compositae), new species, new records and new combinations for Iran. Iranian Journal of Botany 11: $115-127$.

Mozaffarian V. 2008. Flora of Iran, Asteraceae (Compositae): Tribes Anthemideae and Echinopeae, first edition. Institute of Forests and Rangelands Press, Tehran, Iran, Publication No. 59: 169.

Pirkhezri M., Hassani M.E., Hadian J. 2010. Genetic diversity in different populations of Matricaria chamomilla L. growing in Southwest of Iran, based on morphological and RAPD markers. Research Journal of Medicinal Plant 4(1): 1-13. DOI: 10.3923/rjmp.2010.1.13.

Oberprieler C., Himmelreich S., Vogt R. 2007. A new subtribal classification of the tribe Anthemideae (Compositae). Willdenowia 37: 89-114. DOI: 10.3372/wi.37.37104.

Ward J.H. 1963. Hierarchical grouping to optimize an objective function. Journal of the American Statistical Association 58: 236-244. DOI: 10.2307/2282967. 